Western University Scholarship@Western

Department of Economics Research Reports

Economics Working Papers Archive

1978

\title{
Harry Johnson as a Macroeconomist
}

David Laidler

Follow this and additional works at: https://ir.lib.uwo.ca/economicsresrpt

Part of the Economics Commons

Citation of this paper:

Laidler, David. "Harry Johnson as a Macroeconomist." Department of Economics Research Reports, 7813. London, ON: Department of Economics, University of Western Ontario (1978). 
RESEARCH REPORT 7813

HARRY JOHNSON AS A MACROECONOMIST

\author{
by \\ David Laidler
}

April, 1978 
HARRY JOHNSON AS A MACROECONOMIST

by

David Laidler

Paper prepared for a forthcoming JPE Symposium on Harry Johnson's contributions to economics. I am grateful to Victoria Chick, Dennis Coppock, Tom Courchene, Clark Leith, Marcus Miller, Michael Parkin, Don Patinkin, Franco Spinelli and George Zis for comments on an earlier draft which was presented at the Money Study Group University of Manchester Conference, held in memory of Harry Johnson, on April 10-11, 1978. 
Harry Johnson's reputation as a macroeconomist rests at least as much on his contributions to policy debates and on his widely-read survey articles as on his original research. If one looks at his written work from the narrow vantage point of North America, it is easy to underestimate its importance. Much of what his later writings contain was without a doubt "wellknown at Chicago" when it was published. However, Harry's capacity for absorbing "oral tradition" was matched by a considerable ability to contribute to it, and it is dangerous to infer a lack of originality from this fact. In any event, in macroeconomics, his chosen audience more often than not consisted of research workers, teachers and students outside the major centres, not to mention policymakers and "interested laymen." His ability to synthesize and expound the issues being tackled and the results being attained in all areas of the field ensured that their significance was grasped by the profession at large far more rapidly and effectively than otherwise would have been the case. For this reason alone he is a figure of considerable importance in the recent history of macroeconomics.

A number of questions naturally arise. What kind of macroeconomics did he expound? How did it evolve over the years? How much did he himself contribute to the body of knowledge that he expounded? How much did he take from others? And why did the evolution of his thought take the path that it did? Virtually every reader of this paper will already have his own views on the answers to the forgoing questions, and it would be as well to outline mine at the outset. Harry's macroeconomics evolved in a direction that led him to pay increasing attention to monetary factors, but he never became a "monetarist" as the term is understood in North America. ${ }^{1}$ His originality in this area was not of the very highest order but by any reasonable standard it was 
considerable: none of his papers makes a first approach to a new problem, but a number of them represent important contributions to bodies of literature opened up by others. Moreover, his survey papers and policy writings show frequent and highly original insights which he did not always systematically follow up himself. Finally the evolution of Harry Johnson's macroeconomics had very little indeed to do with the fact that he held a Chair at the University of Chicago. The evidence of his published work shows that his views stemmed naturally from his perceptions of what the important issues of macroeconomic policy were, and from his bringing to bear upon those issues the body of theory and empirical evidence that the published macroeconomic literature--including of course those contributions originating in Chicago-provided.

Harry began as what he himself termed a "Cambridge Keynesian." 2 In the early 1950s, like many people working on macro and monetary problems in British universities, he subscribed to two, only loosely connected, bodies of macroeconomics, rather than one. There was pure monetary theory, and knowledge about monetary policy as it was actually conducted and as it actually worked. The former cast only a limited light on the latter. Harry's commentary on Sir Dennis Robertson in the Review of Economic Studies (1951/52), is purely about the logic of an economic model. Despite any clearcut reference, it is obvious that the basis of his analysis is largely Modigliani's (1944) Econometrica paper. One cannot deduce from this essay whether, for example, he believed the fixed or flexible price version of the IS-LM model to be the more relevant, or whether he believed the liquidity trap doctrine to be important or unimportant as a practical matter. To Harry in the early 1950s it 
was the job of economic theory to derive the different implications of different factual assumptions, and that was all. Having just lambasted James Meade in (1951b) for pretending that theory could do more than that. and for slipping his own (liberal) ideology into what purported to be a theoretical discussion as well, it is understandable that Harry was careful indeed about maintaining the purity of his own theoretical writing. ${ }^{3}$ we have to turn to his articles on policy issues to find out what he thought was of practical significance, as opposed to what he knew to be logically true, in macroeconomics.

The 1950s in Britain saw the revival of monetary policy after a long period of pegged interest rates, and direct government control over all aspects of credit allocation. They were also years of creeping inflation. Both circumstances led to substantial academic discussion--and Harry was deeply involved in British debates. His contributions display a considerable uniformity of view until 1956. In 1951, on the very eve of the revival of monetary policy, we find him writing in the Economic Journal about "Some Implications of Secular Changes in Bank Assets and Liabilities in Great Britain." (195la) He noted the immense growth in the money supply, and in the public debt, that had taken place since the 1930s, and because "overcoming inflationary pressure" rather than "chronic defective demand" was likely to be the major policy problem for the future, he expected those "secular banking trends to complicate rather than to ease the problems of economic policy." Although he also looked for "greater cyclical stability of the money supply" to ease "the problems of contracyclical policy," he hastened to note that "Neither of the effects just discussed is one to which any great quantitative significance can reasonably be attached." (p. 556) On the contrary the significant implications of the facts he described was that "overall economic policy will 
rely on budgetary measures, buttressed by some degree of direct controls, rather than on monetary measures." (p. 555) This was partly because the use of interest rate variations "to control private borrowing would have significant repercussions on the cost of the public debt" but also because of "the decline which has occurred in the economic significance of the rates of interest which the joint stock banks directly control" not to mention "the generally accepted view that the interest elasticity of investment is rather low." (p. 554)

Experience during the early years of the "revival" of monetary policy did not change Harry's views about how policy in fact worked, but he did become more forthcoming about how he thought it ought to work. "The revival of quantitative credit control [i.e., a variable interest rate policy] [has] prepared the way for a genuine return to quantitative [i.e., market oriented] methods, should the government in future desire it" (1953, p. 26) but the large volume of floating debt and the "British philosophy of government intervention" (p. 26) made that unlikely. Presumably he was not unhappy about that for he had earlier argued that "The case for rationing credit by price...is largely irrelevant... and open to the objection that the ability to pay high interest is not necessarily a proof of the superior social desirability of the project to be financed." He viewed credit rationing by the banks as opposed to government with suspicion on the grounds "that there is no guarantee that the banks will ration a limited amount of credit in accordance with the National interest." (1952, p. 129) 4

As late as 1956, to judge from his policy writings, Harry's opinions were still much the same. In a major Bank Review article, widely read at the time (1956), he identified the view that the quantity of money is a key policy variable with the view that the total volume of bank credit, as opposed 
to advances, is the central factor. Having thus misunderstood the position, he dismissed it on the grounds that there were many substitute sources of credit for the types of expenditure financed by bank purchases of securities, but not for the inventory investment financed by advances. Hence the cost and volume of bank advances were the important policy variables. (See (1956), pp. 16-17.) "The influence of monetary policy, and the argument for using it, seem to rest chiefly on its effectiveness as a means of controlling stockholding, and possibly also on its influence over short term capital movements; its long run influence on fixed investment is doubtful." Given these views, it is hardly surprising that he concluded that, "...monetary policy is unlikely to be able to do much towards solving the major long run monetary problem of the British economy, the tendency for British wages and prices to increase more rapidly than those of Britain's international competitors. The most that monetary policy could hope to do would be to prevent the problem from being periodically aggravated from over full employment arising from inventory booms." (1956, pp. 18-19)

It was not just because monetary policy was not of any importance in determining aggregate demand that it could not be deployed against inflation. "Substantial unemployment would be required to prevent wages rising at an inflationary rate" so neither monetary policy nor "other means of controlling aggregate demand offer much prospect of a solution." Wage and Price controls and moral suasion would do no good either, because "Such methods attempt to solve the economic problem [of inflation] by ignoring the economic forces which produce it." And what were those forces? "A great deal of the inflationary problem of the post-war years can be attributed to the fact that the increase in productivity since the war has been largely absorbed by increased defence expenditure and the adverse shift in the terms of trade. 
In future, increasing productivity should permit a steady and substantial growth of real income." This would go far towards creating "the necessary condition for a workable 'National wage policy'--the possibility of substantial non-inflationary wage increases." (1956, pp. 29-20) In 1956 then, Harry was a proponent of a rather ill-defined cost-push explanation of inflation based on the failure of real income to rise, and looked to the future feasibility of an even more ill-defined "national wages policy" to deal with the problem.

By 1959, Harry's views had changed markedly. Though he still regarded inflation as a "minor evil" that promised to bring not "major economic catastrophe" (hyperinflation or mass-unemployment caused by balance of payments crisis as, for example, Lionel Robbins and Frank Paish tended to argue), Harry nevertheless recognized that it causes "a host of unfairnesses--some cumulative and some temporary but all irritating--between different members of the community, and makes more complicated and frustrating the tasks of economic calculation for all concerned, including the Government itself." 5 He therefore believed that "the country can probably now afford to trade some loss of output and employment for greater stability of prices." (1959a, p. 151) Because he was "inclined to agree... that the predominant factor [causing inflation] has been high demand" he also agreed that "...demand restriction offers a more effective method of stopping wage inflation than national wages policy. But I would prefer to put the point in another way: that a national wages policy is unlikely to be either acceptable or workable unless backed up by adequate control of effective demand." (1959a, p. 152)

Now this shift to a "demand pull" view of inflation is only one aspect of a change in views that becomes evident in Harry's published work after 1956. He also began to put much more emphasis on the quantity of money when 
discussing policy problems. In 1957 he still believed in the efficacy of direct credit controls. "The real bite of the credit squeeze has been achieved...through directives relating to bank advances... [and] through hire purchase controls" and urged the Radcliffe Committee to consider whether such "methods could usefully be extended to include a closer supervision of building society lending policies." (1957a, p. 343) However, the main burden of the note from which this quotation is taken was to draw attention to the "damning fact" that "no consolidated money supply statement is published in this country." (p. 343) The need to improve published statistics, was the theme of Harry's advice to the Radcliffe Committee (1960) and, by the end of 1958 he had constructed his own annual series for five monetary aggregates for the period 1930-57 (see (1959b); the fact that he was willing to engage in that kind of labor, even with the aid of a research assistant, is evidence enough of the importance that he by then attached to the quantity of money. He saw the explanation for the "shortcomings of existing monetary statistics" as lying "partly in the fact that, though lip service is often paid to the idea that monetary policy seeks to control the quantity of money, such control is actually conceived of in terms of its effects on the availability of money, as reflected particularly in conditions in the discount market and the lending activities of the clearing banks; partly in the fact that the quantity theory of money, which would provide the maximum incentive for the perfection of monetary statistics, has been so completely discredited, in the eyes of most economists, by its Keynesian rival." (1959b, p. 1)

"The Keynesian rival" in question was of course the Hicks-ModiglianiHansen IS-LM model, that had underpinned his commentary on Robertson and to the exposition of which his (1958a) survey of "Monetary Theory and Keynesian 
Economics" was mainly devoted, and the exogenous money wage version of that model at that. However, by 1958 the Pigou effect, which in 1952 had been dealt with in one cryptic parenthetical sentence (see 1951/52, p. 103), was presented as reducing that Keynesian theory to "a special case of...the neoclassical theory..." albeit one that "started from an empirically relevant special assumption, derived some important meaningful results from it, and provided an approach which has since proved its usefulness for a wide range of problems." (1958a, p. 240)

For Harry to criticize the received Keynesian doctrine in these purely theoretical terms was not new in 1958. He had presented much the same argument at a 1954 Conference (cf. 1957b). However, by 1958 he was expressing doubts about its practical relevance too. He was now arguing that the Keynesian model "has shown definite weaknesses as a theory of prices." Inflation models based on it "while they describe the inflationary process...do not explain it very well. The problem of explaining the differing price histories of different countries during and since the war has led to a certain tendency to return to the quantity theory of money. .... It is clear that the accumulation of money during the war has had an important effect; but I would myself prefer to employ a neo-Keynesian explanation, based on the accumulation of assets relative to income, these assets including both money and government debt rather than one which stressed the quantity of money per se." (1958a, pp. 243-44)

Thus, by 1958, and before going to Chicago, Harry had become a very different kind of macroeconomist to the Cambridge Keynesian of the early 1950s. He had of course visited the United States in 1955, and had attended workshops in Chicago, but I can find no evidence of a Chicago influence on his views at this stage, at least on issues of money and inflation. Friedman 
appeared in his writings at this time as a contributor to the literature on the consumption function, not to that on monetary theory or inflation. The quantity theory inspired work which he cites is A. J. Brown's Great Inflation, not the Chicago Studies, and the historical experience to which he refers in the passage just quoted is also that dealt with by Brown. To argue as he did for the importance of carrying out statistical studies of transactions velocity (cf. 1957a) sets him firmly apart from the Chicago School with its emphasis on income velocity, but also suggests the influence of Brown and his associates, particularly in the light of work later carried out under Brown's supervision on transactions velocity. (See Welham 1969.) Moreover, in emphasizing the potential importance of money and government debt he looked back to matters which he himself had analyzed seven years earlier (see pp. 3-4 above), though he now assessed the significance of the relevant data very differently. In short, Harry Johnson's first, large, step away from orthodox "Cambridge Keynesianism" was taken at Manchester, not at Chicago, as a response to what he perceived to be the inability of received theory to deal with an important body of evidence. 6

\section{III}

The years 1959-66, when Harry was full-time at Chicago, saw the writing of his best-known, and most highly regarded, contributions to the macroeconomic literature. The first of these, written during his first year there, was his lecture (1961) on the 25th Anniversary of the publication of. the General Theory. This completed the break with "Cambridge Keynesianism" that had begun at Manchester.

The contribution of the General Theory as presented in that lecture was only loosely related to the IS-LM model which Harry had hitherto referred 
to as "Keynesian." Keynes' "central theoretical contribution [was] that in a monetary economy the stability of employment in the face of changes in aggregate demand for output depends on the uncertain monetary effects of changes in money wage levels, which changes may themselves be slow." (p. 3) "'Unemployment equilibrium' has to be reinterpreted as a disequilibrium situation in which the dynamic adjustment is proceeding very slowly. ...This is a fair modern translation of Keynes's (Marshallian) short period equilibrium technique." (p. 13) ${ }^{7}$ There were weaknesses in the General Theory: Keynes "overgeneralised a particularly bad depression" to give the impression that "large scale unemployment is the typical situation of an advanced capitalist economy," and this was important given his view that "the traditional quantity theory becomes relevant under full-employment conditions." (p. 13) The lack of attention to "the influence of price expectations on the asset demand for money, and the associated necessity of distinguishing between real and nominal interest and between fixed interest bearing securities and equities," (p. 9) and the neglect of the influence of wealth on consumption, were both special cases of the generally "inadequate attention paid in the General Theory to problems of capital theory." (p. 7$)^{8}$ However much harsher criticism was reserved for the "Keynesians." In their hands "a theory in which money is important [has] turned into a theory in which money is unimportant." (p. 15) Their approaches to the problem of inflation "concentrate on the mechanism rather than the causation of inflation; and...virtually assume away the possibility of controlling inflation by monetary means." (p. 16) Their bias against according an important role to money had caused the Keynesian . approach to inflation "to degenerate into a confused and often obstructive eclecticism." (p. 14)

In short, his rereading of the General Theory caused Harry to make his 
own distinction between "Keynesian Economics" and the "Economics of Keynes," and to take the latter as the basis of his own further work in macroeconomics. In the light of this, it is hardly surprising that, though nobody understood the debates about the Classical Dichotomy and the Neutrality of money better than Harry (as several generations of graduate student readers of his (1962) survey have reason to be grateful for) and though nobody enjoyed wrestling with their logical intricacies more than did he (Harry always liked puzzles), he recognized from the outset that the debate had little to do with Keynes's attack on the separation of monetary theory and value theory. "The argument has been concerned throughout with a monetary economy characterised by minimal uncertainty whereas Keynes was concerned with a highly uncertain world..." (1962, p. 17) He reiterated this view in his 1963 survey, concluding that "I do not think that this particular controversy is of great relevance to practical work on monetary policy or monetary analysis, or even I think to monetary theory" (1963d, p. 84) although he explicitly linked this conclusion to the absence of economic growth from the models in question rather than the absence of an analysis of uncertainty and expectations upon which he based the opening of his critique. 9

We have already noted that, much as he admired the book, for Harry the great weakness in the General Theory was a neglect of capital theory, which resulted from Keynes's use of Marshallian short-period equilibrium to deal with problems of dynamic disequilibrium. It was thus work directed to making good this deficiency that he valued most highly. "Friedman's application to monetary theory of the basic principle of capital theory--that income is the yield on capital and capital the present value of income--is probably the most important development in monetary theory since Keynes..." (1962, p. 33) He praised the contributions of Friedman, Modigliani-Ando- 
Brumberg, and Spiro to the consumption function literature for the same reasons, as he did the contributions to the analysis of what we would now term the "transmission mechanism" that "has been emerging in the past few years, from both 'Keynesian' and 'quantity' theorists, as an outgrowth of the formulation of monetary theory as part of a general theory of asset holdings." (1962, p. 50) Again Friedman was cited, this time in company with Tobin, Cagan, and in particular, Karl Brunner, from whose work there was a lengthy quotation, as one who had made an important contribution. But Friedman's contribution in all these cases was seen as being to a theoretical tradition started by Keynes. From the outset Harry was more critical of Friedman's empirical work, and particularly his attempts there to differentiate his approach from the Keynesian tradition as Harry by that time had come to conceive of it.

When he wrote his 1962 survey, Harry had not grasped the interrelationship between Friedman's views on the complexity of the transmission mechanism, the methodology of the famous Friedman-Meiselman study, and the significance of Friedman's (1959) inability to find any well-determined or quantitatively significant relationship between the demand for money and the rate of interest. ${ }^{10}$ He had by 1963, and pointed to "a certain suspicious appropriateness in the Friedman treatment of the cyclical behaviour of velocity." (1963d, p. 102) He returned to this theme more forcefully in his (1965) Economic Journal review article of Friedman and Schwartz's Monetary History arguing that Friedman had deliberately downplayed the interest sensitivity of velocity because, among other things, "to admit interest rates into the demand function for money is to accept the Keynesian Revolution and Keynes' attack on the quantity theory." (1965, p. 396) In terms of Harry's conception of the nature of Keynes'scontribution to economics he was surely right. The liquidity trap 
doctrine played a minimal role in that conception both because "speculation will take the form of movements between securities of different types rather than between securities and cash," (1961, p. 8) and because the available empirical evidence had reduced the existence of a liquidity trap in the demand for money function to a purely semantic issue. (See 1962, p. 38)

Though Harry was not the only reviewer to raise the issue of the interest elasticity of the demand for money--Tobin (1965a) and Meltzer (1965) also made much of it--it was Harry's attack that provoked Friedman (1966) into clarifying his views both on the role of interest rates in the velocity function--they did have a role to play--and on what he believed to be the essential characteristic of Keynesian monetary theory--the liquidity trap. Thus Friedman declined the invitation to embrace the Keynesian revolution, but in doing so he clarified the issues in such a way that those who had regarded him as an anti-Keynesian, but did not regard the liquidity trap as an important ingredient of Keynesian economics, were able to come to a far better appreciation of the significance of his contribution to the subject than they had before. 11

Even so, critical though he often was of it, Harry always took Chicago empirical work seriously, and learned from it. The study of Canadian monetary policy that he and Winder undertook in 1962 was strongly influenced by Friedman and Meiselman (though some aspects of it followed Karekan and Solow's (1963) lead). The conclusion that he drew from that work, "that the effect of monetary policy in the Canadian Economy is imprecise, slow and variable" (1963b, p. 187) led him to argue that monetary policy should be used, not for short-run stabilization policy, but for "creating and maintaining a stable long run monetary environment." (1963b, p. 217) This was the conclusion 
of Friedman, on the one hand, and of the Radcliffe Committee on the other, and in 1963 he was not willing to commit himself either to the Friedman view that stability in the rate of growth of the quantity of money should be the policy target, or to the Radcliffe view that stability of interest rates was the key. ${ }^{12}$ By the next year he noted evidence produced by Friedman showing that the slackening of US aggregate demand in late 1962 was associated with the previous behavior of the moneystock, and was "inclined to attach a greater importance to monetary policy in sustaining the [subsequent] expansion than the Council [of Economic Advisors] does." (1965, p. 251) Moreover the effects in question had been the "unintended consequence of a policy meant to be modestly restrictive in the sense of raising the level of interest rates...that...turned out to be expansionary in its effects on the money supply." (p. 251) And for all criticisms of it, he nevertheless argued that the Monetary History of the United States documented "quite conclusively" the presupposition that "the stock of money is the dominant monetary variable in the economy." (1965, p. 389) Neither in the papers just cited, nor in any other that I have been able to find, did Harry come even close to arguing the quantity of money was all that matters. He thought that money was more important than did the Council but "not to the point of denying that fiscal policy was an important influence on income and employment"; (1964, p. 251) and of course what he regarded as an underemphasis of the importance of real shocks, that stemmed from downplaying the interest elasticity of velocity, was a key element of his criticism of the Monetary History. In 1965 Harry was still by his own lights, a Keynesian. Though he was critical of the underlying methodology of the Friedman-Meiselman study (and of the Monetary History as well), particularly of the insistence that one simple theory be able to explain a long run 
of historical data--"Occam's Razor is a useful principle, but there is no need to cut the throat of empirical research with it" (1965, p. 395)--he accepted its results, and didn't find anything in them to disturb him: "any Keynesian can well argue that the 1930s was the period for which the Keynesian theory was designed... and that in showing that the Keynesian theory works better for that period Friedman and Meiselman have vindicated the Keynesian Revolution." (1963d, p. 102) Nor did he find it difficult to accept the empirical evidence on a stable, albeit interest sensitive, demand for money function. As he later put it, reiterating a view that he had by then long held, "There is...nothing to prevent the absorption of the empirical evidence of a stable demand function for money into the corpus of the Keynesian general equilibrium model...other than the conditioned Keynesian reflex against the 'quantity theory' and the conditioned Keynesian belief that 'money does not matter' (or, at least, 'does not matter much')." (1970, p. 91)

IV

Though very few people would have called Harry a "monetarist" in the mid-1960s (had the label then been in use), he was widely regarded as such in the 1970s, and indeed often found it useful to pin the label on himself. However, I believe that the evidence of his written work shows that he had gone as far towards "monetarism" by the mid-1960s as he was ever to go. A further shift towards monetarism after 1965 is an illusion, but it needs to be explained why it is such a widely believed-in illusion. Part of the explanation lies in the fact that in 1966 Harry took up his Chair at the LSE and "conditioned Keynesian reflexes" were more prevalent in Britain than the United States. Kaldor's (1970) celebrated attack on "The New Monetarism" amounted 
to a denial of the existence of a stable demand for money function and a reassertion of the unimportance of money; thus, in Britain, a Keynesian of Harry's type found himself labelled a monetarist whether he liked it or not. However, other factors were also important. The problems upon which he worked after 1965 required that he lay more emphasis on Friedman's specific contribution to monetary economics than he had previously, a contribution which he had nevertheless much earlier recognized and absorbed into his own thinking.

As early as his 1961 lecture, Harry singled out the failure of Keynes to take account of the influence of inflation expectations and systematically to incorporate the distinction between real and nominal interest rates into his work as an important shortcoming of the General Theory. He called attention to the importance of Friedman's analysis of this problem in terms of a capital theoretic approach to the demand for money, and a recurring theme of his commentaries on monetary economics thereafter was the weakness of those branches of neo-Keynesian monetary theory that neglected this factor. 13 But of course, the influence of inflation expectations is only important as a practical matter if inflation itself is important as a practical matter. As Harry himself remarked, "It is no accident that the appearance of Monetarism as a strong intellectual movement has had to wait until the [inflationary] aftermath of the escalation of the war in Vietnam in 1965." (1971) It is equally no accident that those aspects of Harry's macroeconomics that can most readily be identified as having been learned from Friedman came into prominence in his own work at the same time; the mid-1960s was precisely the time when the analysis of price level movements began to occupy an increasing amount of his attention. Even so, it should be noted now that one characteristic monetarist belief--that there exists no long-run 
inflation-unemployment trade-off--does not, as far as I have been able to discover, and to my considerable surprise, appear in his writings.

Like any other macroeconomist, Harry was compelled by the circumstances of the late 1960s and early 1970s to pay attention to inflation as a policy problem, but he also at that time carried out important original work in monetary theory. Characteristically, there was a substantial spillover from this work on pure theory into his policy writings, and though the theoretical literature to which he contributed has become unfashionable, his work there still retains interest if only because of this spillover. The literature in question is epitomized in the phrases "Money in a growth model," and "money and welfare."

Harry had long been dissatisfied with the literature on the Classical Dichotomy and Neutral Money, both because it was not dealing with the problem in the context of the uncertain world which he regarded as fundamental to Keynesian economics, but also because it abstracted from economic growth. The literature on money and growth meets the second of these objections, but only by completely ignoring the first: that is one reason wny it has now fallen out of fashion. Harry's particular contribution to it (1966b), in contrast to Tobin's initial work (1965b), "stressed the necessity of allowing money a function in a monetary economy and therefore of attributing to the presence of money an increase in economic welfare." (1970, p. 109) In short it incorporated Friedman's analysis of money "as if" a-consumer-durable into the analysis, and showed that, because the rate of inflation influenced holdings of real balances, it would also influence "real income" and hence the savings rate, the details depending upon the way in which savings behavior was modelled. The conclusion established by this literature, and Harry's contribution sets out all the essential results while also managing to be the 
most readable paper on the subject, is that the full employment equilibrium properties of a monetary economy are extremely unlikely to be independent of monetary factors, specifically the rate of change of the nominal money supply, even if all Keynesian problems about uncertainty are assumed away by making inflation, and everything else for that matter, "fully anticipated."14 Since one of those properties is presumably the "natural" unemployment rate, the literature in question may yet turn out to have relevance for important policy issues, but that for the moment must remain to be seen. ${ }^{15}$ My own view is that this is unlikely, and I base it on Harry's judgement of the upshot of the closely related money-and-economic-welfare literature.

As is well-known, Pesek and Saving (1967) showed that the "inside-outside money" distinction of Gurley and Shaw--to which Harry devoted considerable space in his early 60 s surveys--stemmed from endowing accounting conventions with spurious economic content. Once we leave a commodity money world, the key distinction, and this only became clear after a somewhat convoluted discussion to which Harry made an important contribution (see 1969a,b) is between money that bears interest at competitive rates and that which does not because its issue is monopolized. But all the results of the money in growth models literature, and the "schizonphrenic policy proposals" that emerged from Friedman's "Optimum Quantity of Money" (1969) essay hinge upon variations in the rate of nominal monetary expansion influencing the opportunity cost of holding money. Thus, as Harry was quicker than anyone else to stress (see (1968b), they depend on the assumption of a particular institutional anomoly-namely that the monetary system is not compotitive. Only if "the practical point that the payment of interest on currency holdings is infeasible... is taken as being of predominating importance" (1970, p. 107) does the rate of nominal monetary expansion have any long-run significance, and Harry was 
sufficiently unimpressed with its importance that he was willing to abstract from it entirely in his most extensive (1968b) discussion of these very issues. Otherwise as far as he was concerned the welfare analysis of money was significant in two respects: first as a component of the case for more competition in the Banking system, this was an important policy issue in Britain in the late 1960s, and second, inasmuch as it dealt with the transition from commodity to fiat and credit money systems, for the insights that it yielded into the problems of reforming the international monetary system. ${ }^{16}$

The notion of a fully anticipated inflation rate is fundamental to the money-in-a-growth-model-money-and-welfare literature. The recognition that, if agents allow for inflation expectations in their portfolio behavior, they are also going to allow for them in their behavior towards money wages and prices, underlies the literature on the expectations augmented Phillips curve. The "accelerationist hypothesis" follows from the proposition that, in the long run, inflation is indeed fully anticipated--that is, it is expected to occur and behavior is completely adapted to the expectation in question. Like everyone else in the 1960s, Harry was slow indeed to incorporate expectations into his treatment of the Phillips curve, and once he had, though he immediately grasped the logic of the accelerationist hypothesis, he never embraced it.

Harry, writing on inflation in (1963c) is as good an example as one could find of a man who knows something, without knowing that he knows it. He criticized "Keynesian models" that analyze inflation in terms of competition between various social groups for greater shares in national income because unlike the "quantity theory approach," which he identified with the CaganBailey analysis of the inflation tax, they failed to recognize "that the processes of determining wages and prices are fundamentally real processes... ." 
Protection against inflationary redistributions "is available to all groups in a freely competitive system, through negotiation of contracts to take account of expected inflation, and is increasingly resorted to as the fact of inflation is recognised." (1963c, p. 122) He even pointed out that "there are some serious doubts about the applicability of the Phillips curve to the formulation of economic policy....it may reasonably be doubted whether the curve would continue to hold its shape if an attempt were made by economic policy to pin the economy down to a point on it." (1963c, pp. 132-33) Nevertheless, "The Phillips curve appears to be by far the most reliable of [the] relationships" describing statistical trade-offs between policy goals. (p. 133) It formed the basis for his subsequent discussion of policy trade-offs and Reuber's pioneering (1964) attempt to quantify, in dollars and cents terms, the trade-off between inflation and unemployment was held up as an example of the type of work which must be further developed so that the curve could be used as a basis "for intelligent policy making." (p. 141)

It is not difficult to understand why Harry fell into this particular inconsistency. His writings over, the years make it clear that he thought the rapid inflations experienced by underdeveloped countries presented a very different set of problems to the mild inflations of the pre-1970s developed world. ${ }^{17}$ The Phillips curve was a potentially interesting tool for analyzing the latter, while the quantity theory approach had proved its worth empirically in dealing with the former. However, "For the mild type of inflation typical of the United States and other advanced countries... the [quantity theory] approach has not proved nearly so useful... [T] expected rate of price change has not appeared as a significant determinant of the quantity of money demanded." (1963c, p. 126) Because the empirical evidence 
suggested to him that the expected inflation rate was unimportant in such a context, there was no reason for Harry to incorporate it systematically into his thinking about the Phillips curve. Thus even when, in the (1969) Preface to the second edition of Essays in Modern Economics, he noted the inconsistency in question, he argued that it was of more theoretical than practical significance. The importance of incorporating inflation expectations into the Phillips curve "...for the theory of macro economic policy, ...depends on the length of time it takes for changes in expectations generated by experience to begin to affect behaviour significantly; and the empirical evidence is that the lags in adjustment of expectations are sufficiently long for contemporary policy makers safely to disregard them-even though the cumulative effect may be substantial." (p. X)

I have already said that I have found no statement in any of Harry's writings of a belief in a vertical long-run Phillips curve. In his later work he paid increasing attention to the role of expectations in determining the economy's response to stabilization policy and expressed increasing doubts about the theoretical foundations of the Phillips curve itself. Thus, in (1968b), he argued that "stabilisation operations [themselves might disturb] expectations derived from previous experience" by way of "mechanisms [which] cannot be...satisfactorily dealt with by compressing them into the distributed lag structure of the economy." (p. 301) By (1972) he had come to the view that "Contrary to the standard assumptions of economic theory, the economic public does not simply respond mechanically...to signals reaching it through the blind and impersonal operations of...competitive markets. Instead [it] engages in two kinds of political transactions with...policy makers. First, one of its major concerns is to guess how determined the government is about implementing its announced economic policies...second, the relevant 
economic public, aware of the sensitivity of government to political pressure has an incentive to generate such pressures in its own favour." (1972a, p. 104) 18 As to the Phillips curve itself, new work "broadening the micro foundations of the relationship in terms of the influences of information and adjustment costs and other real factors" (1972a, p. 22) was required, a theme which he reiterated at greater length in (1974).

Nevertheless, though he regarded neither the theoretical nor the empirical basis of the relationship as being well established, as an empirical matter he believed in the existence of a long-run trade-off between inflation and unemployment, basing that belief on his reading of the empirical evidence-particularly that of Solow, whose work is cited in the (1969) Survey, the (1972b) Lecture Notes, and the deVries Lectures. ${ }^{19}$ On the empirical nature of the Phillips curve, Harry's position was thus closer to that of Tobin than Friedman and it is worth noting that, in (1971) Harry's major reason for predicting the ultimate failure of the Monetarist counterrevolution, was what he perceived to be monetarism's inability to provide a satisfactory theory of unemployment to complement its theory of inflation. ${ }^{20}$ However, in Britain in the early 1970s, the belief that the excess demand for labor could exert any influence on the inflation rate was enough to get its adherent classified as a monetarist, regardless of his views about the role that inflation expectations, information costs, and such might play in the process, particularly if that view was combined, as it was in Harry's case, with opposition to wage and price controls.

Opposition to direct controls on wages and prices was of course a constant characteristic of Harry's writings on inflation from his very earliest papers in the 50 s to his very last ones. He consistently argued that wage and price controls would make the effects of inflation worse without 
contributing anything to curing the disease. As he put it in (1963c, p. 134), "Does inflation necessarily lead to monetary collapse? The answer is no, provided that the price system is uncontrolled and prices are allowed to rise freely. ... Where monetary breakdowns do occur is where rapid inflation is combined with general price control, so that money ceases to be useable for making transactions...this is the explanation, for example, of the breakdown of the German currency after World War II. ...Does inflation cause economic inefficiency? ...the evidence seems to indicate that inflation does not reduce economic efficiency at least when inflation is mild and reasonably steady and prices and wages are not controlled." Harry's contribution to Parkin and Sumner (1972) and his Preface to the 1977 edition of The Canadian Quandary, reiterate much the same views, albeit with extra vehemence, borne of the fact that he was then discussing controls as a

- current policy issue rather than from a purely academic point of view. Once" more though, let it be noted that, if opposition to such controls is cited as evidence of "monetarist leanings" on Harry's part, then he had acquired those leanings long before going to Chicago. (Cf. p. 5 above.) Though Harry's role in developing the monetary approach to balance of payments theory is beyond the scope of this paper, some mention must be made of it at this point, because a misunderstanding of Harry's own view of that theoretical development has also contributed to the opinion that he was a "monetarist." In (1974) he accepted that "The criticisms directed at this approach for its neglect of dynamic disequilibrium behavior, [and] the processes of international transmission of monetary impulses...are certainly justified by the published literature of the approach as it now stands." (1974, p. 224) However he argued that "some at least recognize that reality occupies the area between the closed and open economy theoretical assumptions, 
very much as the problem of how the effects of monetary impulses are divided between price and quantity responses defines the gray area requiring intensive empirical research in contemporary closed-economy monetary economics." (p. 224) His own research program at the LSE was "intended to pursue this matter in depth." In short, Harry's published writings on the monetary approach, "monetarist" though their characteristics undoubtedly were, were meant to set out a theoretical basis for organizing empirical work, not to state his beliefs about the nature of the world.

There is no neat and tidy ending to the story of the development of Harry's macroeconomics. He had always paid more attention than the majority of contributors to the area to open economy problems, and by 1969 had come .to the conclusion that "Perhaps the greatest disservice Keynes rendered to the development of economics [in Britain] was to develop the theory of macroeconomics and money on the assumption of a closed economy. The extension of Keynesian theory to an open economy... has been built on the manifestly unsatisfactory assumption of money illusion on the part of wage earners... Much work remains to be done in developing a monetary economics appropriate to the analytical and policy problems of the British economy." (1970, p. 114) Thereafter the development of what has come to be called "The monetary approach to balance of payments theory" occupied an increasing proportion of his time, so that the 1970s saw very little from him that falls within the traditional boundaries of macroeconomics.

His Oxford Economic Papers survey article, already alluded to, and the 1977 Journal of Economic Literature paper, written jointly with Bob Nobay, are the only major pieces of work. The latter, extending ideas originally 
set out briefly in the deVries lectures and later in a note in Kredit und Kapital (1976), is certainly interesting for the parallels that it draws between the pre-Keynesian analysis of short-run monetary equilibrium and recent developments in American monetarism, especially those associated with the work of Lucas, Sargent and Wallace on rational expectations. However, it lies outside of the mainstream of his later work. That, to repeat, concerned the macroeconomics of the open economy and to deal with it would take me beyond the assigned scope of this paper. Let it be stressed though, that Harry never regarded that work as dealing with a separate field. He viewed it as a natural development of his work on macroeconomics and money in which he integrated Friedman's notion of a stable demand for money function with his own, much earlier, attempts at generalizing balance of payments theory (see 1958b). Thus the reader of this essay should weigh his work on the monetary approach to balance of payments theory along with the contributions with which this essay has dealt when he assesses Harry's importance as a macroeconomist.

of course, it is far too early to carry out such an assessment in any final way. What can be done though is to sum up the salient features of Harry's macroeconomics as it emerges from the work which has been surveyed in this essay. First and foremost of course, it is remarkable for its breadth, but it is also remarkable for the consistency of its approach. In particular, at every stage we can see that Harry paid particular attention to empirical evidence in forming his views. It was the inflation of the 1950s that persuaded him to pay more attention to monetary factors; it was his own empirical work, and that of Brown and of Friedman and his associates that persuaded him of the particular importance of the quantity of money and of the futility of using monetary policy for short-run stabilization policies; it was empirical 
evidence drawn from underdeveloped countries that persuaded him of the importance of the peculiarly "Chicago" contribution to monetary economics, namely the role of inflation expectations in influencing the demand for money; and it was empirical evidence that led him to his views on the importance of inflation expectations in the context of the policy problems of developed countries. Closely related to his respect for empirical evidence is the consistency with which he searched for policy relevance in his macroeconomics. Debates about the Pigou effect, neutrality, and the classical dichotomy, were examined for such relevance and found wanting; the literature on money-welfare-and-growth provided him with tools to analyze the reform of domestic banking and the international monetary system; he always regarded unemployment as a more important policy problem for developed countries than inflation, so Friedman's contributions were to him a complement to Keynes' economics, not a substitute; and his LSE research program was designed to investigate the empirical content and policy relevance of the monetary approach to balance of payments analysis. For Harry Johnson "the purpose of economics as a Social Science is to arrive at a set of principles for understanding and interpreting the economy that are both scientifically 'robust' and sufficiently simple to be communicable to successive generations of students and policy makers and the general public." (1974,p. 214) No one worked more diligently and consistently to further that purpose than did he. 


\section{FOOTNOTES}

$1_{\text {The evolution of Harry's macroeconomics was of course but one as- }}$ pect of his evolution as a political economist. Over the years he undoubtedly moved from "left" to "right." This was not because he became increasingly confident in the powers of market forces to solve social problems, but rather because he became increasingly pessimistic about the willingness and ability of governments and bureaucracies to solve those same problems. He said as much in the closing passages of the Preface to the 1977 edition of his Canadian Quandary. It is far beyond the scope of this essay to go into all of these matters. However, let me assert that just as his macroeconomics evolved as he subjected economic analysis to empirical evidence, so I am sure that similar forces governed his broader devejopment. The contrary view, proposed by Bhagwati (1977), that Harry's views changed as a result of "arguing with an ideologue," will no doubt appeal to anyone too lazy to engage in a similar exercise on his own account.

2 See Ronald I. McKinnon (ed.) (1976), p. 298.

${ }^{3}$ In later years, Harry was the first to admit that the review in question was unfair. Nevertheless it illustrates an important trait in his work. Though usually the most generous of critics, that generosity vanished immediately when, rightly or wrongly, he thought that economics was being pressed into the service of either a particular ideology or a particular personal ambition.

4 The reader should note that the comment on the "ability to pay high interest" comes from a footnote. A useful account of the contents of the entire symposium, in which Harry, who gives the impression of having been a very serious young man indeed--recall that he was not yet 30--came in for more than a little leg pulling from Sir Dennis Robertson and Victor Morgan, is to be found in Hutchison (1967). 
$5_{\text {As }}$ far as mild inflation in developed countries was concerned, Harry's views never changed from those expressed here. Indeed, in (1963e) he presented empirical evidence that led him to believe that, if anything, mild inflation was conducive to economic growth.

6 Two points need to be made about the foregoing paragraphs. First, the Pakistan Economic Journal article, though published in 1958, has its origins in a lecture delivered in the summer of 1956. I am unable to comment on how close the final published text of the article is to that of the original lecture. Also, it should be noted that there was in no sense a "sudden conversion" of Harry Johnson to the quantity theory of money as a result of reading Brown's Great Inflation. He reviewed the book in the 1956 Economic Journal but without any great enthusiasm for it. Finally, note that the absence of any reference to the Chicago Studies in Harry's work up to 1959 may simply reflect the fact that the book was not available in England. Reviews of it did not appear, as far as I have been able to discover, in any British journal before 1959 .

7 Harry acknowledges the work of Clower, Leontief, and Patinkin in developing this idea. He does not give references to specific papers.

. 8 The reader will note that Leijonhufvud was later to disagree with this judgement. Note though that there is no disagreement between the Johnson 1961 Essay and Leijonhufrud's book on the importance of capital theory for Keynesian economics. Their sole disagreement concerned the extent to which Keynes had recognized and coped with this problem himself.

$9_{\text {Harry did qualify the foregoing judgement in one respect. He thought }}$ the Gurley-Shaw inside money concept was important as a theoretical matter because of its implications for the Pigou effect. In the light of the outcome 
of the Pesek-Saving debate, his judgement here was of course erroneous. If we have interest-bearing money, it is not net wealth, but the LM curve is going to be vertical (or at least steep) so there's no need for a Pigou effect. If there is room for substantial variation in the opportunity cost of holding money, on the other hand, it must be because money does not bear a competitively determined rate of return and hence is, on the margin, net wealth.

- ${ }^{10}$ See (1962) as reprinted in Essays in Monetary Economics, p. 41 . The only way that I can make sense of the first paragraph on this page is to think that Harry was confused between the effects on the transmission mechanism of monetary policy of perfect interest elasticity and perfect interest inelasticity of the demand for money function. The Friedman-Meiselman study was not of course in its final form when Harry wrote this 1962 survey article. As I recall it, the first draft of that study did not contain an account of the transmission mechanism--though Harry urged the authors to include one--so it is perhaps understandable that he was somewhat muddled on this particular issue at that time.

${ }^{11}$ Friedman's reply to criticism on this score was published in the Journal of Law and Economics (1966). His subsequent exchange with Tobin (see Gordon (ed.) (1974)) essentially goes over all this ground again without advancing matters any further. In fairness to Friedman, it should be noted that there is much in the literature on Keynesian economics to justify his view of the central role of the liquidity trap doctrine, particularly the British literature. See, e.g., Hicks (1957) or Kaldor (1970).

12 This matter is discussed in (1963b). On pp. 217-18 of the EME reprint, the reader will find a perfect statement of what would now be called the "Poole problem." Cf. Poole (1971). The contribution of Alvin Marty to this 
paragraph is acknowledged, but it still stands as a particularly good example of the way in which Harry would put highly original formulations of problems into his survey papers and policy writings and then not systematically follow them up afterwareds.

${ }^{13}$ In particular, the work of Tobin and the Yale School on portfolio behavior is systematically criticized for this. See, for example, (1970) and (1974); but note that Tobin's work on money and economic growth is immune to this criticism.

${ }^{14}$ See $(1966 \mathrm{~b})$. Some of the analysis there presented is further developed in the latter half of "Inside Money, Outside Money...," JMCB (1969). ${ }^{15}$ I am indebted to Douglas Purvis for some discussions on this point. ${ }^{16}$ On the international monetary system see "A Note on Seignoirage and the Social Saving from Substituting Credit for Commodity Money" (1968a). On competition in banking, see "The Report on Bank Charges" (1967).

17 See (1966a).

${ }^{18}$ In the first of these quotations the reader will recognize the germ of the "rational expectations" idea. The second quotation represents a substantial extension of the notion, and one that has not yet been taken up in the analytic literature.

${ }^{19}$ of course he should not have taken Solow's results seriously, because those tests were flawed. See Laidler (1970). However, it is easy to forget that in 1971 virtually all the available empirical evidence seemed to show that there was a long-run inflation-unemployment trade-off. It has only been with the growing sophistication of the modelling of expectations that results favorable to the long-run vertical Phillips curve have been generated. By the time that work was produced, Harry was mainly working on other matters. 
${ }^{20}$ The Ely Lecture, to which I refer here, caused quite a stir when it was delivered containing, as it did, attacks both on Keynes' and Friedman's means of propagating their ideas. If anything, that lecture is a contribution to the sociology of knowledge rather than to macroeconomics, and that is why I do not pay more attention to it here. It is ironical that Harry himself was subsequently criticized along identical lines in connection with his work on the monetary approach to balance of payments theory. See Hahn (1977) and Coppock (1978). 
PAPERS BY HARRY JOHNSON REFERRED TO IN THE TEXT

(Note that page numbers of quotations refer to the original sources unless a reprinted source is explicitly referred to below.)

(1951a) "Some Implications of Secular Changes in Bank Assets and Liabilities in Great Britain," Economic Journal, vol. 61 (September 1951), pp. 544-61.

(1951b) "The Taxonomic Approach to Economic Policy," Economic Journal, vol. 61 (December 1951), pp. 812-32.

(1951-52) "Some Cambridge Controversies in Monetary Theory," Review of Economic Studies, vol. 19 (2) (1951-52), pp. 90-104.

(1952) "The New Monetary Policy and the Problems of Credit Control," Oxford University Institute of Statistics Bulletin, vol. 14 (April-May 1952), pp. 117-31.

(1953) "Recent Development in British Monetary Policy," American Economic Review (Papers and Proceedings), vol. 43 (May 1953), pp. 19-26.

(1956) "The Revival of Monetary Policy in Britain," Three Banks Review, no. 30 (June 1956), pp. 3-20.

(1957a) "The Determination of the General Level of Wage Rates," in Dunlop, J. (ed.), The Theory of Wage Determination, Macmillan (1957).

(1958a) "Monetary Theory and Keynesian Economics," Pakistan Economic Journal, vol. 8 (June 1958), pp. 1-70; reprinted in Clower, R. (ed.), Monetary Theory, Penguin (1969).

(1958b) "Towards a General Theory of the Balance of Payments," in International Trade and Economic Growth, Allen and Unwin (1958).

(1959a) "Two Schools of Thought on Wage Inflation," Scottish Journal of Political Economy, vol. 5 (1959), pp. 149-53.

(1959b) "British Monetary Statistics," Economica, vol. 26 (February 1959), pp. 1-17.

(1960) "Memorandum of Evidence," in Committee on the Working of the Monetary System Principal Memoranda of Evidence, vol. 3, London: HMSO (1960).

(1961) "The General Theory After Twenty-Five Years," American Economic Review, vol. 51 (May 1961), pp. 1-17. 
(1962) "Monetary Theory and Policy," American Economic Review, vol. 52 (June 1962), pp. 335-84; reprinted in Essays in Monetary Economics (EME) (2nd ed.), George Allen and Unwin (1969).

(1963a) The Canadian Quandary, Toronto: McGraw-Hill (1963). Carleton Library edition (1977) .

(1963b) "Alternative Guiding Principles for the Use of Monetary Policy in Canada," Princeton UP (1963). (Essays in International Finance, no. 44, November 1963.); reprinted in EME.

(1963c) "A Survey of Theories of Inflation," Indian Economic Review, vol. 6, no. 4 (August 1963); reprinted in EME.

(1963d) "Recent Developments in Monetary Theory," Indian Economic Review, vol. 6, no. 4 (August 1963), pp. 1-28; reprinted in EME.

(1963e) "Objectives, Monetary Standards and Potentialities," Review of Economics and Statistics 45 (October 1963), pp. 137-47.

(1964) "Major Issues in Monetary and Fiscal Policies," Federal Reserve Bulletin (November 1964), pp. 1400-13; reprinted in EME.

(1965) "A Quantity Theorist's Monetary History of the United States," Economic Journal, vol. 75, no. 298 (I!une 1965), pp. 388-96.

(1966a) "Is Inflation the Inevitable Price of Rapid Development or a Retarding Factor in Economic Growth?" in Krivine, D. (ed.), Fiscal and Monetary Problems in Developing States (3rd Rehovoth Conference), New York: Praeger (1966), pp. 121-37; reprinted in EME.

(1966b) "The Neo-Classical One-Sector Growth Model: A Geometrical Exposition and Extension to a Monetary Economy," Economica (August 1966), pp. 265-89; revised and reprinted in EME. 
(1967) "The Report on Bank Charges," Bankers Magazine, vol. 204, no. 1481 (August 1967), pp. 64-8; reprinted in Johnson et al. (eds.), Readings in British Monetary Economics (RBME), Oxford: Clarendon Press (1971).

(1968a) "A Note on Seigniorage and the Social Saving from Substituting Credit for Commodity Money," Punjab University Economist, vol. 6, no. 9 (June 1968), pp. 1-8; in Mundell, R. A. and Swoboda, A. K. (eds.), Monetary Problems of the International Economy, Chicago: Chicago UP (1969), . pp. 323-29.

(1968b) "Problems of Efficiency in Monetary Management," Journal of Political Economy, vol. 76, no. 5 (September-October 1968), pp. 127-51; reprinted in RBME.

(1969a) "Inside Money, Outside Money, Income, Wealth and Welfare in Contemporary Monetary Theory," Journal of Money, Credit and Banking, vol. 1, no. I (February 1969), pp. 30-45.

(1969b) "Pesek and Saving's Theory of Money and Wealth: A Comment," Journal of Money, Credit and Banking, vol. 1, no. 3 (August 1969), pp. 535-37.

(1970) "Recent Developments in Monetary Theory--A Commentary," in Johnson, H. G. and Croome, D. (eds.), Money in Britain, 1959-69, Oxford: Clarendon Press (1970) .

(1971)

"The Keynesian Revolution and the Monetarist Counter Revolution," American Economic Review (Papers and Proceedings) (1971); reprinted in Further Essays in Monetary Economics (FEME), London: George Allen and Unwin (1973).

(1972a) Inflation and the Monetarist Controversy, the 1971 deVries Lectures, Amsterdam (1972) .

(1972b) Lectures on Macroeconomics and Monetary Theory, London: Gray-Mills (1972).

(1974) "Major Issues in Monetary Economics," Oxford Economic Papers (1974).

(1976) "Comment on Mayer on Monetarism," Kredit und Kapital (1976).

(1977) (with A. R. Nobay), "Monetarism: A Historic Theoretical Perspective," Journal of Economic Literature (June 1977). 
WORKS OF OTHER WRITERS REFERRED TO IN THE TEXT

Bhagwati, J. N., "Harry G. Johnson," Journal of International Economics 7 (August 1977), pp. 221-30.

Brown, A. J., The Great Inflation, 1939-1951, London: Oxford UP (1955).

Coppock, D. J., "The Monetary Theory of the Balance of Payments--A Commentary," University of Manchester (mimeo) (1978).

Friedman, M., "The Demand for Money - Some Theoretical and Empirical Results," Journal of Political Economy 67 (June 1959), pp. 327-51.

, "Interest Rates and the Demand for Money," Journal of Law and Economics 9 (October 1966).

" "The Optimum Quantity of Money," in The Optimum Quantity of Money and Other Essays, London: Macmillan (1969). (ed.), Studies in the Quantity Theory of Money, Chicago: Chicago UP (1957).

Friedman, M. and Meiselman, D., "The Relative Stability of Monetary Velocity and the Investment Multiplier in the United States, 1898-1958," in Commission on Money and Credit: Stabilization Policies, Englewood Cliffs, NJ: Prentice-Hall (1963).

Gordon, R. J. (ed.), Milton Friedman's Monetary Framework, Chicago: Chicago UP (1974).

Gurley, J. and Shaw, E., Money in a Theory of Finance, Washington, DC: Brookings Institution (1960).

Hahn, F. H., "The Monetary Approach to the Balance of Payments," Journal of International Economics 7 (August 1977), pp. 231-50.

Hicks, J. R., "A Rehabilitation of 'Classical' Economics?" Economic Journal (June 1957), pp. 278-89.

Hutchison, T. W., Economics and Economic Policy in Britain 1946-1966, London: George Allen and Unwin (1968). 
Kaldor, N., "The New Monetarism," Lloyds Bank Review (July 1970), pp. 1-18.

Kareken, J. and Solow, R., "Lags in Monetary Policy," in Commission on Money and Credit: Stabilization Policies, Englewood Cliffs, NJ: Prentice-Hall (1963). Laidler, D., "Recent Developments in Monetary Theory - Discussion Paper," in Johnson, H. G. and Croome, D. (eds.), Money in Britain 1959-1969, London: Oxford UP (1970).

Leijonhufvud, A., On Keynesian Economics and the Economics of Keynes, London: Oxford UP (1968).

McKinnon, R. I. (ed.), Money and Finance in Economic Growth and Development Essays in Honor of Edward Shaw, New York and Basel (1976).

Meltzer, A. H., "Monetary Theory and Monetary History," Schweizerische Zeitschrift Volkswirtschaft und Statistik (Spring 1965), pp. 409-22. Modigliani, F., "Liquidity Preferance and the Theory of Interest and Money," Econometrica (1944), pp. 45-88.

Parkin, J. M. and Sumner, M. T. (eds.), Incomes Policy and Inflation, Manchester: Manchester UP (1972).

Pesek, B. P. and Saving, T. R., Money, Wealth, and Economic Theory, New York: Macmillan (1967).

Poole, w., "Optimal Choice of Policy Instruments in a Simple Stochastic Macro Model," Quarterly Journal of Economics 84 (May 1970), pp. 197-216.

Reuber, G. L., "The Objectives of Canadian Monetary Policy 1949-61: Empirical Trade-Offs and the Reaction Function of the Authorities," Journal of Political Economy 72 (April 1964), pp. 109-32.

Tobin, J., "The Monetary Interpretation of History," American Economic Review LV (June 1965a), pp. 464-85. - "Money and Economic Growth," Econometrica 33 (October 1965b), pp. 671-84.

Welham, P., The Monetary Circulation of the United Kingdom, Blackwell Oxford (1969). 